\title{
Making boards effective: An empirical examination of board task performance
}

\begin{abstract}
Despite the increasing attention of management scholars to board of directors, there is still scant evidence on the antecedents of board task performance. The lack of significant results seems to be due to some theoretical and methodological choices followed by scholars, i.e. the almost exclusive reliance on agency theory and the use of demographic data. Following the call for dismantling the fortresses dominating past studies, this article contributes to open the 'black box' of board of directors developing a conceptual model that considers the impact of board members' diversity, commitment, and critical debate on board task effectiveness in performing its service and control tasks. We collected primary data through a questionnaire survey, and we tested the model controlling for board, firm, and industry characteristics. Our findings suggest that: (i) the predictors we identified, and particularly the board members' commitment, are far more important than board demographics to predict board task performance; (ii) firm and industry contexts exert a significant influence on board task performance; (iii) predictors have a different impact on specific sets of tasks. Thus, our findings support the idea that several board characteristics and contingencies at both industry and firm level must be acknowledged in board design.
\end{abstract}




\section{Making boards effective: An empirical examination of board task performance}

\section{Introduction}

Despite the increasing attention of management scholars on corporate governance and board of directors, empirical evidence on the relationship between board composition and structure on the one hand, and boards' outcomes or corporate financial performance on the other hand is still equivocal (Dalton et al., 1998; Dalton et al., 1999; Hermalin and Weisbach, 2003; Johnson, Daily, and Ellstrand, 1996). This lack of significant results seems to be due to two common characteristics of past research on board of directors: (1) the almost exclusive reliance on agency theory, and the resulting strong emphasis on the board control tasks; (2) the search for a relationship between board composition and firm financial performance, and the consequent lack of processoriented board research (e.g. Daily, Dalton and Cannella, 2003; Roberts, McNulty, and Stiles, 2005; Stiles and Taylor, 2001).

First, since Berle and Means (1932) identified the problems associated with the separation between ownership and control, the dominant theoretical lens used in corporate governance studies has been agency theory (e.g. Dalton et al. 1998; Daily, Dalton, and Cannella, 2003). Agency theory dominates corporate governance studies as it proposed the first satisfactory explanation of the separation between ownership and control in large public companies (Jensen and Meckling, 1976). Further, it was founded on a well accepted model of man (Daily, Dalton, and Cannella, 2003). However, the strong reliance on agency theory led scholars and practitioners to assign strong emphasis on board control tasks and to assume board effectiveness to be a function of its independence from management (Roberts, McNulty, and Styles, 2005). 
With respect to the second point, governance studies have focused on the relationship between board demographic variables and board's or company's performance (e.g. Daily, Dalton, and Cannella, 2003; Johnson, Daily and Ellstrand, 1996; Pettigrew, 1992). The implicit assumption behind these studies is that demographic variables are superior to behavioural and process variables because they are directly observable, and hence their measure is more reliable and valid (Pfeffer, 1983). However, some scholars have recently argued that the use of demographic variables in presence of complex group dynamics, as in boardroom decision-making, cannot be able to predict board or firm performance (e.g. Daily, Dalton, and Cannella, 2003; Forbes and Milliken, 1999; Johnson, Daily, and Ellstrand, 1996).

A recent special issue of the British Journal of Management (vol. 16, 2005) underlined the importance of analysing board effectiveness through the empirical examination of board behaviour. Roberts, McNulty and Stiles (2005) explored the concept of accountability through a qualitative survey of directors of FTSE 350 companies. They argued that while board demography conditions board effectiveness, it is the real behaviour of board members to determine board effectiveness. Active directors' behaviour - i.e. challenging, questioning, informing, encouraging, etc. - is an important driver of board effectiveness. Pye and Pettigrew (2005) pointed out the importance to focus on context, process and time to understand board dynamics. They called for the development of a new theoretical framework in board process research, with the purpose to avoid confusions among cause and effect relationships, and input and output variables across multiple levels of analysis. Huse (2005) provided a framework for exploring behavioural perspectives on boards and governance. This framework is characterized by: (1) splitting the link between board composition and corporate financial performance in intermediate steps (e.g. Zahra and Pearce, 1989); (2) 
using a pluralistic approach to board role theories (e.g. Johnson, Daily, and Ellstrand, 1996; Zahra and Pearce, 1989); and (3) applying theories from group and cognitive psychology to understand boards as decision-making groups (e.g. Forbes and Milliken, 1999).

Following the call for dismantling the fortresses of past research on boards of directors (Daily, Dalton, and Cannella, 2003), this article aims to develop and to empirically test a theoretical model on the impact of board characteristics on board task performance. We considered board task performance as the ability of the board to perform six tasks related both to service (advice, networking, and strategic participation) and control (behavioural, output and strategic control) (Huse, 2005). Building on previous studies (e.g. Forbes and Milliken, 1999; Huse, 2005; Milliken and Martins, 1996; Zahra and Pearce, 1989), we identified three antecedents of board task performance: board members' diversity, commitment, and critical debate. We collected data through a survey directed to CEOs of large Italian companies. We tested the model using a multiple ordinary least squares (OLS) regression analysis. We controlled for the most investigated board demographic characteristics (i.e. board size, CEO duality, CEO and directors' shareholding, and proportion of outside directors), and for firm- and industry-level variables. Our findings support the idea that: (i) the predictors we identified, and particularly the board members' commitment, are far more important than board demographics to predict board task performance; (ii) firm and industry contexts have an influence on board task performance; (iii) predictors have a different impact on specific sets of tasks. Consequently, our findings support the idea that several board characteristics and contingencies at both industry and firm level must be acknowledged in board design. 
The article is divided into four sections. In the first section, we present the theoretical model considering the relationship between board members' diversity, commitment and critical debate on the one hand, and board task performance on the other hand. In the second section we describe the research method, presenting the sample, the data collection and the operationalization of dependent and independent variables. Then, we present the results of the study. In the final section, we discuss our main results and their implications for research and practice.

\section{Theoretical background}

\section{Board tasks}

Board tasks have been categorized in several ways, but the most common distinction is between board service and control tasks (Forbes and Milliken, 1999). Literature on boards of directors has traditionally considered resource dependence theory and agency theory as the main theoretical perspectives to support respectively the service and the control tasks of boards (Forbes and Milliken, 1999; Johnson et al., 1996; Stiles and Taylor, 2001; Zahra and Pearce, 1989).

According to the resource dependence theory (Daily and Dalton, 1994; Pfeffer, 1972; Pfeffer and Salancik, 1978), boards of directors perform a service task and are supposed to bring different types of resources to the firm. Among the different potential benefits provided by corporate boards, advice and counsel on the one hand, and external legitimacy and networking on the other hand are considered to be particularly valuable (Hillman and Dalziel, 2003). With respect to advice and counsel, the board of directors should actively evaluate and select strategic alternatives developed by top managers and supply suggestions to improve the quality of strategic decision-making (e.g. Andrews, 1980; Demb and Neubauer, 1992; Lorsch and MacIver, 1989; Styles and Taylor, 2001). 
Concerning the external legitimacy and networking, the boards of directors usually coopt outside directors to increase firm's legitimacy in its environment (Johnson, Daily and Ellstrand, 1996; Zahra and Pearce, 1989) and to improve relationships with relevant stakeholders (Pfeffer and Salancik, 1978).

According to agency theory, rooted in economics and finance, agents are opportunistic and are strongly motivated to take profit from the information asymmetry between them and their principals (Fama, 1980; Jensen and Meckling, 1976). Following this premise, agency scholars believe that the primary task of boards of directors is to safeguard shareholders' interests from management misappropriation (Shleifer and Vishny, 1997). From this perspective, boards of directors are groups of independent people that have the duty to actively control top management behaviours and decisions in order to secure the shareholders' value maximization (Fama and Jensen, 1983). The board control tasks includes a set of related activities, such as controlling the company's performance, monitoring the activities performed by the firm, and assessing CEO's behaviour (e.g. Johnson, Daily, and Ellstrand, 1996; Stiles and Taylor, 2001; Zahra and Pearce, 1989).

A recent review of board tasks underlined that the adoption of different focuses allows for a more thorough definition of the different tasks the board can perform. Moreover, it allowed to further specify the different sets of tasks within the broader definition of service and control (Huse, 2005). Board tasks can have, in fact, internal, external and strategic focus, depending on the actors the board wants to address with the performance of a specific task. The adoption of different focuses illuminates six sets of board tasks. Specifically, advice and counsel, networking and lobbying, and strategic participation are service-related tasks, and refer respectively to internal, external and strategic focus. In the same vein, the adoption of internal, external and strategic focus 
allows for the definition of the control-related tasks, i.e. behavioural control, output control and strategic control. All the previous sets of tasks rely on other complementary theoretical perspectives than resource dependence and agency theory only.

Among the service tasks, the advisory task is based on both the stewardship theory and the resource based view of the firm and has an internal focus. According to stewardship theory, founded on a positive view of human behaviour, people are not inclined to opportunism, and managers want to sincerely pursue shareholders' interests (Davis, Schoorman, and Donaldson, 1997). In this view, boards of directors are groups of competent people that help managers to enhance their decision-making process, e.g. contributing to the boardroom debate through their experiences, competences, and different viewpoints. In other words, board members provide advice and support to top managers, and thus represent a valuable resource for corporate boards (Donaldson and Davis, 1991). The networking task is based on the resource dependence and social network theory and has an external focus. It roots in the relationship between the firm and its external stakeholders, and contribute to the firm legitimacy purpose. According to this view, the main contribution of boards of directors is to guarantee the company a steady flow of critical resources. In other words, board members are known and powerful persons that take profit of their personal networks in order to increase the legitimacy, the reputation and the stock of resources controlled by the company (Pfeffer, 1972; Pfeffer and Salancik, 1978). The strategic participation task is based on the stewardship theory and has a strategic focus. This task consists in the board involvement in all the different phases of the strategic decision process (i.e. the formulating, evaluating, and implementing). The board contribution to the strategic decision process is considered an important factor leading the company to gain a competitive advantage in the industry (Andrews, 1980). 
The adoption of different focuses identified also three sets of board control tasks, i.e. the behavioural control, the output control, and the strategic control tasks. The behavioural control task is based on agency theory and has an internal focus. It consists in monitoring the CEO and the top managers' behaviour (Boyd, 1995). The primary driver of these activities is the obligation to ensure that management operates in the interests of shareholders, an obligation that is met by scrutiny, evaluation, and regulation of the actions of top management by the board (Hillman and Dalziel, 2003). The output control task is based on both agency theory and stakeholder theory and has an external focus. This task consists basically in the monitoring of firm corporate financial performance. Given the problems involved in the direct observation of management behaviour, due to the asymmetry of information between directors and managers, board control task is largely performed through an active monitor of firm performance respect to shareholders and stakeholders expectations (Eisenhardt, 1985; Fama and Jensen, 1983). Finally, the strategic control task is based on agency theory and the legal view of the corporation, and has a strategic focus. Strategic control task consists in both evaluating and monitoring strategic decision making (Stiles and Taylor, 2001). This task is particularly important when critical choices must be made, such as acquiring a new firm, divesting a division, or negotiating a takeover bid (Baysinger and Butler, 1985; Zahra and Pearce, 1989).

\section{Board characteristics and board task performance}

Despite the increasing attention of management scholars to board of directors, there is still scant evidence of the antecedents of board task performance (e.g. Daily, Dalton, and Cannella, 2003; Pye and Pettigrew, 2005). A large number of studies investigated the existence of a significant relationship between board characteristics (mainly board 
demographics) and firm performance without finding any clear and consistent result (e.g. Dalton et al., 1998; Dalton et al., 1999; Johnson, Daily, and Ellstrand, 1996).

The lack of significant results is mainly due to some theoretical and methodological choices followed by governance scholars, and led to calls for dismantling existing fortresses of extant research (Daily, Dalton, and Cannella, 2003). The failure of board demographic characteristics to predict board or company's performance resulted in increased attention to board behavioural aspects rather than to board composition and structure (Finkelstein and Mooney, 2003; Forbes and Milliken, 1999; Pettigrew, 1992; McNulty and Pettigrew, 1999). Further, it emphasized that board task performance is determined by a dynamic of interactive effects, and it is difficult to identify proper predictors of board task performance (Pye and Pettigrew, 2005).

To the purpose of this article, we followed insights from Huse (2005), Forbes and Milliken (1999) and Milliken and Martins (1996) to identify other board characteristics than board demographics to predict board task performance. In his framework to explore behavioural perspectives on boards and governance, Huse (2005) identified the board decision-making culture as the main predictor of its actual task performance. Specifically, he indicated commitment, creativity and criticality among the core variables defining a boardroom decision-making culture (Huse, 2005; Huse, Minichilli and Schøning, 2005). Similarly, Forbes and Milliken (1999) argued for three key board processes as having a potential to impact on board task performance. They are effort norms, i.e. the group level shared beliefs regarding the level of efforts individuals are expected to put towards their tasks; cognitive conflict, i.e. the task-oriented difference in judgment among group members; and the presence and use of both general and firmspecific knowledge and skills. Finally, a large literature on group effectiveness underlines that diversity may have a strong impact on group-level outcomes (e.g. 
Milliken and Martins, 1996; Simons, Pelled and Smith, 1999). Managerial research on the effects of diversity in group composition led to the conclusion that it may significantly affect outcomes (e.g. turnover and performance) through its impact on affective, cognitive, and communication processes (Milliken and Martins, 1996). This is particularly true with regard to underlying attributes of team members, such as the diversity of board members' professional background.

Following the previous arguments, we identified three potential predictors of board task performance. They are board members' background diversity, which defines the 'presence' of knowledge and skills within the board, and two variables related to the board decision-making culture, which together define the 'use' of such knowledge and skills (Forbes and Milliken, 1999). These decision-making culture variables are the commitment of board members, and the critical debate inside the boardroom (e.g. Forbes and Milliken, 1999; Huse, 2005). 'Presence' and 'use' of knowledge and skills are considered as being relevant predictors of the board willingness and ability to effectively performs the different set of tasks we identified in the previous section (Forbes and Milliken, 1999).

\section{Board members' background diversity}

The concept of diversity has its roots in the organizational field, and has been widely investigated as a potential predictor of team performance. Diversity has several possible meanings and a common distinction in the managerial literature is between diversity on observable attributes (such as race, age and gender), and diversity on underlying attributes (such as education, technical abilities, functional background and personality characteristics) (Milliken and Martins, 1996). This distinction is relevant because diversity in underlying attributes is more 'job' or 'task-related' than diversity in 
observable traits of group members, and has thus a higher potential to impact on group task performance. For example, diversity in functional background is typically jobrelated since it captures 'experience, information, and perspectives relevant to cognitive tasks' (Simons, Pelled, and Smith, 1999, p. 663).

Among the underlying attributes of group members, background diversity is considered particularly relevant in organizational settings and it is mostly used to conduct research at the top management team and at the board level (Milliken and Martins, 1996, p. 404). Board members' professional background diversity (e.g. lawyers, consultants, managers, academicians, etc.) captures how much the group members differ each other on their experiences, competences, skills, and perspectives.

Skill- or knowledge- based diversity may produce positive cognitive outputs, because it increases the likelihood of creative and innovative solutions to problems. On the other hand, it may also generate some negative consequences, e.g. integration problems among group members. The ambiguity of the effects of group diversity on group-level task performance emphasized in past research (e.g. Carter, Simkins, and Simpson, 2003; Hambrick, Cho, and Chen, 1996; Pelled, Eisenhardt, and Xin, 1999; Robinson and Dechant, 1997) calls for a close consideration of the relationship between board diversity and the different board tasks we considered. In other terms, board members' background diversity cannot be beneficial or detrimental per se, but its effects can vary among the different outcomes we expect from the board discussion.

For our purposes, a major divide is represented by the board service tasks and the board control tasks. For the board service tasks we considered the advisory, the strategic participation, and the networking task performance. The advisory task is about mentoring and supporting the management, while the strategic participation task requires board members to be involved in the initiation and implementation phases of 
the strategic process (Huse, 2005). In both cases, background diversity appears to have a negative impact on task performance. Support to management and participation in the strategic process require specialized knowledge, and thus higher background diversity is likely to scatter board members' competences and skills on several unrelated issues. Moreover, it has been argued that diversity might have a negative impact on the ability a team of persons has to reach a strategic consensus (Knight et al., 1999), and might even inhibit the examination of opportunities and threats and the long range planning (Miller, Burke, and Glick, 1998). In addition to that, higher background diversity is likely to create 'faultlines' among board members, reduce their potential of creativity (Lau and Murnigham, 1998), and favour information asymmetries. For the networking task, instead, the background diversity implies different professional categories represented in the boardroom. A variety of professional profiles (such as lawyers, bankers, academics) should predict a greater involvement in networking, door opening, and legitimating (Huse, 2005). Therefore:

Hypothesis 1a: The board members' background diversity is negatively related to: (i) advisory and (ii) strategic participation task performance; while it is positively related to (iii) networking task performance.

As for the control tasks, executive directors are a stable and powerful group of people that strongly influence board's activity. The increase in the diversity of board members, through the nomination of non-executive directors with different backgrounds, may generate a great variety of perspectives being considered in decisionmaking. This variety of viewpoints may increase board independence, since people with a different expertise and knowledge are likely to ask questions that would not come 
from boards made almost exclusively by executive directors (Erhardt, Werbel, and Shrader, 2003). In this vein, board members' background diversity may be associated with board effectiveness in its oversight function. The previous arguments are especially true for the output control, which implies examination of financial reports and procedures. Behavioural control and strategic control, yet, require a more thorough knowledge of internal behaviours and practices, and thus background diversity and the presence of outside board members negatively relates to these control tasks (Baysinger and Hoskisson, 1990). Therefore, we hypothesize the following:

Hypothesis 1b: The board members' background diversity is negatively related to: (i) behavioural control and (ii) strategic control task performance; while it is positively related to (iii) output control task performance.

\section{Board members' commitment}

The concept of board members' commitment relates to calls coming from several scholars in boards and governance research, according to which enhanced board members' effort in board activities results in virtuous circles and board empowerment (Demb and Neubauer, 1992; Lorsch and MacIver, 1989; Huse, 2007). This concept has been also addressed as the board members' 'will' in using power sources within the structure and context of boards (Pettigrew and McNulty, 1995). Board members' commitment refers to both the preparation before meetings and the involvement during meetings. The board members' preparation refers to their willingness and ability to participate board meetings with a deep knowledge of the topics to be discussed in order to actively contribute to the decision-making process. Preparation is related to the degree to which board members examine information before meetings and take 
initiatives to collect further information (Forbes and Milliken, 1999). The board members' involvement during meetings refers to the effort they devote during discussions, and in the follow up of the decisions taken during the board meetings (Judge and Zeithaml, 1992; Pearce and Zahra, 1991); involvement also includes board members' willingness and ability to advance useful questions and to intervene constructively in the board decision-making process. The similarity and the empirical correlation between the two concepts led management scholars to use them as a single concept (Huse, 2005).

With respect to board service tasks, board members' commitment means their will to participate each phase of the strategic decision-making process (Westphal, 1999). A high level of board members' commitment implies stronger effort, which may enhance the group performance (Latane, Williams, and Harkins, 1979). Therefore, we can hypothesize that that higher the board members' commitment, the higher the board's ability to perform its service tasks. In particular, Forbes and Milliken argued that the 'time that directors devote to their tasks can differ considerably across boards, and these differences can significantly determine the degree to which boards are able to represent shareholders' interests successfully and to make contributions to strategy' (Forbes and Milliken, 1999, p. 493). Moreover, Lorsch and MacIver (1989) argued that board members that devote sufficient time to their duties and seek out the information they need are better able to govern effectively in times of crisis. Finally, Pettigrew and McNulty (1995) defined as 'maximalist' boards where power is widely dispersed and the non-executives members may have an impact on the direction of the firm. Following the previous arguments, we then hypothesize: 
Hypothesis 2a: The board members' commitment is positively related to: (i) advisory, (ii) networking, and (iii) strategic participation task performance.

Board members' commitment may also be crucial for the board to effectively perform its control tasks. According to Lorsch and MacIver (1989), board members who devote enough time to accomplish with their duties are better able to prevent and manage crises. Passive boards have been also associated with bankruptcy (Daily and Dalton, 1994). Moreover, careful preparation before meetings, and a clear and accurate knowledge of the firm financial position are prerequisites for board effectiveness with respect to the output control. On the other side, the critical attitude, and the willingness to ask the management discerning questions during board meetings allows for board members to exert effective behavioural and strategic control. Therefore, we hypothesize that board members' commitment positively predicts the board performance in all the three sets of control tasks:

Hypothesis 2b: The board members' commitment is positively related to (i) behavioural control, (ii) output control, and (iii) strategic control task performance.

\section{Board critical debate}

The concept of critical debate is related to the concept of 'conflict' the previous literature on teamwork has presented. Conflicts have been broadly defined as 'perceptions by the parties involved that they have discrepant views or have interpersonal incompatibilities' (Jehn, 1995, p. 257). In this vein, conflicts have a dual nature, and can be beneficial to the group, as well as detrimental (e.g. Eisenhardt and 
Schoonhoven, 1990). Following Priem and Price (1991), it is important to distinguish between emotional interpersonal conflicts emerging from non task-related disagreements and personal dissensions, and task-related disagreements. On the one hand, personal dissensions result in non task-related disagreements, with the potential to determine negative emotions that diminish interpersonal sympathy among group members, reduce their satisfaction, and lower their desire to continue working together (Forbes and Milliken, 1999). Conversely, task-related disagreements are differences in opinions that groups experience about the content of the activities, including the differences due to different points of views and personal ideas. Thus, they are 'taskoriented differences in judgment among group members' (Forbes and Milliken, 1999, p. 494), with the potential to increase the quality of the debate, leading the directors to consider a broader range of alternatives and to take a better final decision (Forbes and Milliken, 1999).

As pointed out by Eisenhardt, Kahwajy and Bourgeois in their study on top management teams, 'teams whose members challenge one another's thinking develop a more complete understanding of the choices, create a richer range of options and ultimately make the kinds of effective decisions necessary in today's competitive environments' (Eisenhardt, Kahwajy and Bourgeois, 1997, p. 2). As a matter of fact, several researchers have suggested that this wider range of options may cause the need to reconcile diverse solutions, which in turn may stimulate effective group discussion leading to high quality decisions (Wanous and Youtz, 1986). We refer to the positive effects that task-related conflicts or disagreements may produce through the concept of critical debate. Critical debate can improve strategic decision-making also because it facilitates the exchange of information among the board members (Amason and Sapienza, 1997). Team members disagree because their different perspectives cause 
them to see different scenarios, and these differences (and the critical debate they produce) can enhance decision quality. Bantel and Jackson (1989) argue that complex decisions are best solved by teams with a variety of skills, knowledge, abilities and perspectives. Schweiger and colleagues (1986) found that interaction techniques that force team members to disagree and debate the merits of different alternatives produced superior decisions. Therefore, diversity among solutions critical debate produces is important to group performance (Maier, 1970; Hoffman, Harburg, and Maier, 1962). Along this line, we argue that critical debate is functional with respect to the board ability to perform its service tasks. Therefore we hypothesize the following:

Hypothesis 3a: The board critical debate is positively related to: (i) advisory, (ii) strategic participation, and (iii) networking task performance.

Critical debate may cause critical and investigative interactions to arise (Amason, 1996), which in turn may result in increasing level of board monitoring performance (Forbes and Milliken, 1999). Critical debate is likely to enhance board monitoring performance in two different ways. First, disagreements among board members may result in a higher level of investigations and critical questions. Moreover, disagreements may be associated with an atmosphere of openness, where each director feels free to express his or her personal opinions and doubts on how the firm is managed (Cadbury, 2002). As a consequence, disagreements may lead the CEO to provide more detailed information and explanations on his conduct and decision-making. Second, disagreements in previous meetings may be perceived by the CEO as a signal of board power, and the CEO may thus be more prone to prepare the information needed before 
meetings and to take into account the interests of shareholders (Forbes and Milliken, 1999).

Critical debate may be especially relevant for behavioural, strategic and output control task performance (Huse, 2005). Critical debate is more likely to arise when the issues faced by the board are complex and ambiguous. In these circumstances, board members are likely to express different opinions and contrasting viewpoints (Dutton and Jackson, 1987). Critical debate may be of particular importance when control tasks entail a higher level of uncertainty and ambiguity. For instance, the degree of ambiguity and uncertainty may be particularly high when board members are trying to evaluate whether alternatives proposed by the CEO are in the best interests of shareholders (behavioural control), when the board should take critical strategic decisions such as mergers and acquisitions (strategic control), and when the board should develop plans and budgets (output control). Therefore, we hypothesize the following:

Hypothesis 3b: The board critical debate is positively related to: (i) behavioural control, (ii) strategic control, (iii) output control task performance.

The theoretical model describing the relationship between board characteristics and board task performance is presented in Figure 1.

- Insert Figure 1 about here -

\section{Methods}

Corporate governance in Italy

The Italian corporate governance system, together with other European countries (such as France, Spain, Portugal, and Greece), can be classified in the Latin subgroup 
characterized by controlling shareholders, strong inter-company ties and a weak role of capital markets (De Jong, 1997).

Italian companies are traditionally under the influence of a controlling shareholder, usually represented by a family, a multinational company or the State. Large blockholders, especially wealthy families, maintain the control of large listed companies through a vast array of governance mechanisms: the listing of many companies belonging to the same group, the issue of shares with limited voting rights, high leverage, mutual inter-group shareholdings, and shareholders' agreements (Zattoni, 1999).

Existing regulation does not allow banks and other financial institutions to own large shareholdings in industrial companies. Moreover, financial institutions do not usually exert a significant influence on the governance of large companies due to existing corporate practices (e.g. multiple loans with different banks). Institutional investors do not play a relevant role because of their limited shareholdings, their strict connections with the Italian banks and a regulatory environment that does not favor their activism. Finally, the stock market plays a limited role and the market for corporate control is almost absent. In sum, the Italian governance system can be described as a system of 'weak managers, strong blockholders and unprotected minority shareholders' (Melis, 2000, p. 354).

Italian companies are characterized by a particular board structure. The shareholders' general meeting must, in fact, appoint both a board of directors and a board of statutory auditors, whose main task is to monitor the directors' performance. Some researches published in the ' 90 s showed that the board of directors of large Italian companies was under the direct influence of controlling shareholders (e.g. Molteni, 1997; Melis, 2000). Board composition was characterized by the presence of inside 
directors (i.e. large shareholders and executives) or outside directors related to them by family or business ties, while the independent directors were only co-opted to increase the firm's reputation and legitimacy. Boards did not create committee on specific tasks (e.g. nomination, remuneration, and audit committee), and the executive committee tended to absorb most of its key tasks. Finally, there were few board meetings, the information sent to directors was incomplete and filtered by managers, there was neither an ex ante definition nor an ex post formal evaluation of directors' contribution.

Recent reforms both in the commercial law and in the corporate best practices have contributed to radically change the Italian governance system. As for the second point, the introduction and the update of a code of best practice (1999 and 2002) has contributed to improve governance practices at board level by encouraging transparency in the appointment of directors, a larger proportion of non-executive and independent directors, the adoption of boards committees, the definition of stringent internal control systems, a more active role of statutory auditors, and the monitoring of transactions with third parties. The most recent version (2006) of the code of good governance made a further step in the evolution of board practices by encouraging companies to introduce a lead independent director in firms with CEO duality, providing a list of examples to be used by the board in evaluating the directors' independence, favoring independent directors meetings, and recommending the yearly self-assessment of the board. These institutional changes have contributed to improve governance standards and to empower boards of directors in large Italian companies (Zattoni, 2006).

\section{Sample and collection of data}

The analysis we conducted bases on a questionnaire survey sent to CEOs of the 2,000 largest Italian industrial companies ranked by turnover. This choice is in line with 
governance studies incorporating primary data, that are traditionally based on a single respondent, mostly the CEO (e.g. Pearce and Zahra, 1991; Zahra, 1996; Zahra, Neubaum and Huse, 2000). The decision to have a single respondent is due to the difficulties to gain access to primary data on boards of directors, because of their tendency to conduct business in secret (e.g. Daily, Dalton, and Cannella, 2003; Pettigrew, 1992). Further, we chose the CEO as key informant because he or she is supposedly knowledgeable about the issues investigated in our study, and probably is in a better position than other board members to report on them. We used some procedural techniques to reduce the risk of common method bias. Our cover letter guaranteed anonymity to moderate respondents' tendency to make socially desirable responses (Podsakoff et al., 2003). We devoted careful attention to the wording of questions in order to avoid vague concepts and to reduce items ambiguity (Tourangeau, Rips, and Rasinski, 2000). Finally, in our questionnaire the dependent and the independent variables were placed far apart from each other (Parkhe, 1993).

The research on board of directors has usually had low response rate (often lower than $20 \%$ ) since board members are busy professionals, and further they know private information that cannot be revealed outside the company (Pettigrew, 1992). In order to increase as much as possible the response rate we devoted a particular care in the design of the questionnaire. In particular, we (1) made a pre-test to fine tune the questionnaire, (2) prepared a presentation letter, emphasizing the need for research on board of directors and increasing the interests on the topic, (3) sent a second questionnaire three months later (Carpenter and Westphal, 2001; Fowler, 1993; Groves, Cialdini, and Couper, 1992). Given these cautions, we received 301 responses. The overall response rate was about 15 percent. 
We collected archival data on companies through AIDA and Datastream, two databases including financial and more general information, to check for nonrespondent bias. We used the Kolmogorov-Smirnov test (Siegel and Castellan, 1981) to understand if there were significant differences between respondent and non-respondent companies regarding variables such as size, performance, and industry. The results showed no significant differences between the two groups of companies.

\section{Dependent variables}

Data related to dependent, independent and control variables have been collected through the questionnaire survey. Both dependent and independent variables have been built using groups of items measured through a 1-5 Likert scale. The dependent variables related to the six board tasks discussed in the theoretical section (Huse, 2005).

The advisory task has been measured using five items. In particular, we asked the CEOs to assess the degree to which the board provides advice on (i) management issues (e.g. organizational structure or company strategy), (ii) financial issues (e.g. leverage or relationships with banks and other financial institutions), (iii) technical issues (e.g. new technologies or new products), (iv) market issues (e.g. entry in new industries or consumer behaviour), and (v) legal issues and taxation. The variable advice was thus built as a mean of the previous items. The Cronbach alpha is .82 .

As for the networking task, we asked the CEOs to rate the degree to which the board (i) provides linkages to important external stakeholders (banks and financial institutions, customers, public authorities etc.), and (ii) provides the firm with external legitimacy and reputation. The variable networking was built as a mean of the two items. The Cronbach alpha equals to .83 . 
The strategic participation task has been measured through three items. These items aimed to estimate the degree to which the board is actively involved in (i) promoting strategic initiatives, (ii) taking strategic decisions, and (iii) participating to the implementation phase of long term strategic decision-making. The variable strategic participation was built as a mean of the three items. The Cronbach alpha equals to .83 .

The behavioural control task has been measured asking the CEOs to what extent the board was involved in (i) monitoring that all the internal behaviours are adequately controlled, (ii) defining behavioural guidelines for divisional and functional managers, and (iii) directly supervising the CEO. The variable behavioural control was built as a mean of the three items. The Cronbach alpha equals to .62 .

The output control task has been measured through three items. Specifically, we asked the CEOs to value the extent to which the board (i) controls that the activities are well organized, (ii) develops plans and budgets, and (iii) keep informed on the financial position of the company. The variable output control was built as a mean of the three items. The Cronbach alpha equals to .71 .

Finally, the strategic control task has been measured on a single 5 point-scale item. We asked the CEOs to express their opinion about how much the board was actively involved in monitoring and evaluating the strategic decisions.

\section{Independent measures}

The independent variables included in the study are board members' background diversity, commitment, and critical debate.

The board members' background diversity has been measured considering the diversity of directors' backgrounds represented in the board (Milliken and Martins, 1996). We asked the CEOs to identify the board members' background according to 
different categories (e.g. managers in other companies, consultants, academics, lawyers, etc.). Our measure tried to capture background diversity as the number of different background categories represented in the board over the total number of board members.

The board members' commitment has been measured using 7 items, including both the preparation and involvement concepts (e.g. Forbes and Milliken, 1999; Huse, 2007). The preparation has been measured asking the CEOs the degree to which: (i) directors examine information before the meetings, and (ii) actively collect further information to those supplied by managers. Involvement has been measured quantifying the extent to which directors: (iii) devote all the time needed to accomplish with their tasks, (iv) are available to fulfil board activities, (v) effectively use their knowledge, (vi) make useful questions to proposals advanced by managers, and (vii) raise critical points during meetings. The Cronbach alpha for this variable equals to .76 .

The board critical debate has been measured as a mean of five items (e.g. Forbes and Milliken, 1999; Jehn, 1995). These items were measured asking the CEOs to evaluate the extent to which disagreements emerge within the board of directors on (i) the decisions to be taken during the board meetings, (ii) the firm's legitimate stakeholders, (iii) the company's general purposes, (iv) the board working styles, and

(v) the decision process. We also considered the (vi) disagreements among board members, and thus the level of conflicts inside the boardroom. The Cronbach alpha in this case equals to .91 .

\section{Control variables}

The controls we adopted in our analyses refer to industry, firm, and board level. At industry level, we controlled for the degree of industry regulation. This variable has 
been measured asking the CEOs to evaluate on a 5 points Likert scale the degree to which the industry was regulated.

We controlled also for size and listing at the firm level. The firm size has been measured as firm turnover. A logarithmic transformation was used to control for heteroskedasticity. We also introduced a dummy variable to control for listing status (1=listed company).

We controlled then for the board demographics: CEO duality, the number of directors, the outsider ratio, and the board members shareholding (Finkelstein and Mooney, 2003). The board size and the percentage of non-executive directors have been measured asking the CEOs to indicate the number of board members and the number of non-executive directors. Several cross-checks have been performed to avoid biases and misunderstandings especially with respect to the number of non-executives in the boardroom. CEO duality has been measured as a dummy variable $(1=$ yes $)$ basing on the CEOs' indications. Finally, we controlled for the percentage of board members with shareholdings in the firms, measured as the number of board members with shareholdings on the total number of directors.

\section{Results}

Table 1 shows the means, the standard deviations, and the bivariate correlations for the variables used in the regression analyses.

- Insert table 1 about here -

The correlation analysis showed no significant figures among the independent variables, and showed mostly expected results. The correlations among the different 
board tasks we considered are particularly high. It is not surprising, since active boards will be likely active in all service and control tasks, and will hardly perform these tasks selectively. In particular, the correlation between behavioural control and output control was the highest we recorded $(.73 * *)$.

The regression analyses have been realized considering three different models for each of the board tasks we presented. The first model includes the control variables we selected. The second model considers the four board demographics to test their predictive power with respect to the board tasks. The last model includes our independent variables. Table 2 shows the standardized beta coefficients of the regression analyses we performed.

- Insert table 2 about here -

The first set of regressions considers the advisory task as the dependent variable. The first two models with control variables and the board demographic characteristics show a limited explanatory power. The $\mathrm{Adj}^{2}$ is only $.04^{*}$ and $.06^{* *}$ respectively. Nonetheless, in the second model regulation $\left(.17^{* *}\right)$ and listing $\left(.19^{* *}\right)$ have a positive impact on advice, while among the board demographics the board size negatively impacts on this task $\left(-.19^{* *}\right)$. The last model is significant and robust. The $\operatorname{Adj} \mathrm{R}^{2}$ is $.31^{* * *}$, with a high value of the F-change $(30.4 * * *)$, and all the three predictors we considered are significant. More specifically, both critical debate (.11*) and commitment $\left(.50^{* * *}\right)$ have a positive impact on advice, while the background diversity is negative $\left(-.14^{*}\right)$. The last model enlightens that critical debate favours mentoring and strengthens the strategic decision process, and that commitment is a strong prerequisite for board advice to management. Background diversity, then, inhibits advice since 
directors with different professional backgrounds will have problems in providing constructive and technical advice on managerial issues.

The second set of regressions considers the networking as dependent variable. Again, the first two models show a limited predictive power, and the $\operatorname{Adj}^{2}$ is only $.04^{* *}$ and $.06^{* *}$ respectively. The third model is more robust, even though the $\operatorname{Adj}^{2}$ is definitely lower than for the advisory task $\left(.14^{* * *}\right)$. This model shows that among the demographic variables only board members shareholding is relevant $\left(.17^{* *}\right)$, while among the predictors we selected, critical debate $\left(.12^{*}\right)$ and commitment $(.29 * * *)$ are significant. The rationale is that boards with higher board members' ownership are more willing to door opening and external legitimacy, and make use of external directors to engage critical debate and brainstorming on how to enhance firm reputation and credibility.

The third set of regressions considers the strategic participation task. Similarly to the other tasks, the models with control and demographic variables have a limited predictive power. Nonetheless, the third model is particularly robust (the $\operatorname{Adj}^{2}$ is $.38^{* * *}$, with an F-change of $\left.36.9^{* * *}\right)$, and shows interesting results. Firm size and outsider ratio are negatively related to strategic participation task (respectively $-.17 * *$ and $-.11 \dagger)$, while regulation positively predicts strategic participation $\left(.12^{*}\right)$. Among our predictors, commitment has a positive impact on strategic participation $\left(.55^{* * *}\right)$.

With respect to the control tasks, the behavioural control and the output control tasks show the most robust results. As to the output control task, also the model with the control variables shows some predictive power $\left(.09^{* * *}\right)$. It is given to the strong impact of listing $\left(.28^{* * *}\right)$ on control. The last model, then, is robust (the $\operatorname{Adj}^{2}$ is $.33^{* * *}$, with an F-change of $28.8^{* * *}$ ), and shows other interesting predictions. Besides listing, regulation $\left(.11^{*}\right)$, board size $\left(.17^{* *}\right)$ and commitment $\left(.47^{* * *}\right)$ have a positive impact 
on output control, while board background diversity is negatively related to this task ($.20 * *)$. The last result deserves special consideration. Similarly to what we hypothesized with respect to advice, board members' homogeneity seems to be more beneficial than diversity. Output control implies monitoring over financial results, and their deviance from budgets. With respect to this, the background diversity hampers rather than fosters the board task performance. This is consistent with what we found for behavioural control, which shows similar relationships to output control, even though the overall model is less robust $(.22 * * *)$. Finally, the model for strategic control is the weakest, with an $\operatorname{AdjR}^{2}$ of only $.05^{* *}$. In this model, the commitment is the only significant predictor $(.28 * * *)$.

In sum, the analyses confirm all the hypotheses related to commitment (Hypothesis 2a-2b), since board members' commitment shows in all circumstances a strong and positive impact on different board tasks. With respect to background diversity, the analyses confirm hypotheses $1 \mathrm{a}$ in relation to advice task performance and $1 \mathrm{~b}$ in relation to behavioural task performance. Finally, about critical debate only hypothesis 3a in relation to advice and networking task performance is confirmed.

\section{Discussion}

Our findings contribute to increase the understanding of board task performance. Specifically, they show that (i) the predictors we identified, and particularly the board members' commitment, have a larger impact on board task performance than board demographic characteristics; (ii) firm and industry contexts exert a significant influence on board task performance; (iii) predictors have a different impact on specific sets of tasks, i.e. board design implies balancing trade-offs. Taken together, our findings 
support the idea that several board characteristics and contingencies at both industry and firm level must be acknowledged in board design.

\section{Reconsidering the antecedents of board task performance}

Our analysis shows that the set of board demographic characteristics previous research often investigated has a limited predictive power in understanding how the board performs its service and control tasks (Finkelstein and Mooney, 2003; Zona and Zattoni, 2007). Among the few relationships we highlighted, our results indicate that larger boards favour both behavioural and output control tasks, whilst they may inhibit advice. The rationale is that larger boards have usually a larger presence of outside directors and thus they are more independent. Such board composition is particularly favourable to control tasks, while limits the advice which is likely to be stronger in smaller and more homogeneous boards. This result is in line with the strong emphasis on the firm external accountability (i.e. internal audit and financial reporting) that listing rules and codes of good governance impose, especially on listed companies (Roberts, McNulty, and Stiles, 2006).

Our predictors seem to be more powerful antecedents of board task performance than board demographics. Among them, board members' commitment has the strongest and most significant influence on all board tasks we considered. Commitment was defined as the time and preparation devoted by directors before meetings, and as the involvement in board discussion with critical questions and observations. Our study suggests that boards of directors should carefully consider the importance to create a process-oriented boardroom culture which favour board members' commitment to board activities (e.g. Forbes and Milliken, 1999). This result follows evidence in past studies, according to which active and committed boards better serve their corporation 
(Millstein and MacAvoy, 1998). It also strengthens the idea that creating an internal culture encouraging an active behaviour of board members is an essential ingredient of board effectiveness (e.g. Finkelstein and Mooney, 2003; Lorsch and MacIver, 1989; Mace, 1986; Stiles and Taylor, 2001). To this purpose, some governance practices favour the emergence of an internal culture of commitment and will (Pettigrew and McNulty, 1995). Among them, the introduction of regular board reviews might foster a board learning process, and enhance board members' involvement and commitment in their duties and tasks (e.g. Kiel and Nicholson, 2005). Along this line, the chairman plays a critical role in shaping the board culture, and he or she may transforms a minimalist board toward a maximalist one (Pettigrew and McNulty, 1995).

Board critical debate, then, shows a positive impact on board advisory task, as hypothesized. This result is in line with previous studies, according to which one of the most important prerequisites for board members' engagement in board tasks is the presence of a challenging boardroom environment, characterized by open debate and informal dialogue among executive and non-executive board members (McNulty and Pettigrew, 1999). Similarly, critical debate has a positive impact also on networking task, suggesting that cognitive disagreements on the firm goals and purposes result in board members' convincement that external legitimacy is essential to firm survival and success.

The third predictor we considered is board members' background diversity. Board members' background diversity shows a negative impact on advisory task, and on behavioural and control tasks. This evidence strengthens the idea that there might be some trade-offs between potential positive and negative effects of board members' diversity (Milliken and Martins, 1996). The predicted negative impact of board members' background diversity on some of the board tasks we presented calls for an 
active role of nomination committees inside corporate boards. Given these trade-offs between potential positive and negative effects of board members' diversity, nomination committees should careful consider the selection and retention of valuable individuals within their boards, with peculiar emphasis on the selection and retention of outside non-executive board members, in order to secure the overall balance of skills the company needs (Ruigrok et al., 2006).

\section{The role of firm and industry contexts}

Our results show also that firm (size and listing) and industry (regulation) contexts may influence board task performance. The impact of listing on the pressure boards experience to perform their tasks relates to the recent spread of codes of good governance in the stock exchanges. These codes emphasize the importance to provide qualified advice to the $\mathrm{CEO}$ and the management, and to control for the quality of outputs and for the directors' behaviour (Aguilera and Cuervo-Cazurra, 2004). Behavioural control, in particular, is increasingly becoming essential to avoid risks of various forms of management's expropriation favoured by transactions with related parties. The negative impact of firm size on strategic participation task performance supports the view that in large companies the complexity of the organizations may undermine the board contribution in all the phases of the strategy-making process (Zahra and Pearce, 1989).

The impact of industry regulation is even stronger and relates to both service and control tasks. More specifically, industry regulation has an impact on advice, strategic participation, behavioural control and output control. This evidence suggests that boards in regulated industries feel more comfortable in their task performance since they rely considerably on the existence of rules and standards which define the boundaries of the 
firm's activities. It strengthens a contingency argument, showing that boards' effectiveness relates to the contexts in which they operate, and that different predictors are useful to explain board task performance under different contingencies (Pye and Pettigrew, 2005).

\section{The need of balancing trade-offs in board design}

Our study shows that board characteristics and firm and industry contexts have different predictive power on the board ability to perform its tasks. Our findings suggest that in order to catch how board characteristics affect board task performance, the established dimensions of board tasks (service and control) are too roughly defined. The lack of significance may be overcome looking at the more refined relationship with each of the six tasks we considered (Huse, 2005).

\section{- Insert Table 3 about here -}

We summarized in table 3 the significant predictors on the six board tasks. The table offers several insights on how to make boards effective. In particular, it illuminates whether certain board predictors are more relevant than others in explaining the board effectiveness with respect to the different sets of tasks we considered. Our results suggest the lack of clear relationships between the different board characteristics and the different tasks boards perform. Both independent and control variables predict board tasks in different ways. The only persistent result is that board members' commitment is a key variable to carefully consider in creating a process-oriented decision making culture inside the boardroom. Besides commitment, board members' background diversity and critical debate show different predictive power on the various tasks. 
Moreover, different contingencies both at firm and industry level seem to explain why boards engage in given tasks more than others, giving further indications to improve governance practices, with particular emphasis on the key role of the nominating committee.

The previous arguments strengthen the importance of a contingency approach to board tasks, and to what make boards effective (Strebel, 2004). Boards are likely to place emphasis on some board tasks according to the contingencies the firms are experiencing. Past studies showed how board members' involvement in their activities and tasks, and especially that of 'part-time' or non-executives, is contingent upon the stage of the firm life cycle (McNulty and Pettigrew, 1999). In this respect, it has been argued that 'board members' involvement $[\ldots .$.$] is greater at those points in the life-$ cycle of firms that involve strategic transitions' (McNulty and Pettigrew, 1999, p. 67). This issue is critical and still under investigated. Future studies are encouraged to refine our knowledge on how variations in context may influence the dynamic interplay of board practices, processes, and performance over time (Pye and Pettigrew, 2005).

\section{Conclusions}

The purpose of this article was to provide a better understanding of what makes boards effective in the performance of their tasks. In our empirical examination we decided to move beyond the board demographic characteristics (Finkelstein and Mooney, 2003), and to consider other outcomes variables than corporate financial performance. This purpose was pursued through an empirical test of the impact of some board characteristics on the board performance of the six tasks identified by Huse (2005). Basing on the results of our analyses, we gave indications on how to design effective boards, which implies also how to select and retain board members, how to 
incentive board members' commitment, and how to lead discussions in the boardrooms to stimulate or avoid disagreements.

Our study suffers also of two main limitations, which deserve to be carefully acknowledged. First, our study provides some preliminary insights on how board characteristics and processes might impact on different board tasks. However, we recognize that board task performance is determined by a number of dynamic interactions among several process variables that require further consideration and studies. In other words, the lack of a well established theoretical framework on board processes makes it difficult to identify proper predictors of board task performance (Pye and Pettigrew, 2005).

Second, we selected CEOs as single respondents. This choice may imply the risk that CEO presents an idealized version of events, and it does not solve the problem to know that the same risk applies also to chairpersons and other board members (including the non-executive directors). Unfortunately, the use of multiple respondents has also its limitations, and it is likely to produce even more biases. Perceptual agreements problems are, in fact, likely to determine frequent dissimilarities among reports of competent multiple respondents, and constructing an organizational response out of divergent reports might bias even more the results (Kumar, Stern, and Anderson, 1993). In sum, despite the various reasons that support our choice to rely on CEOs' view, the risk of normative and single respondents' biases must still be recognized.

Finally, our study opens room for future research in this area. First, our results need to be further tested and explored in other institutional settings or with respect with other classes of companies, for example SMEs. Moreover, our study has a cross-sectional research design, and so it may undermine board dynamics. Future longitudinal studies might improve our knowledge of board interactions and processes, strengthening the 
consistency of our findings. Finally, our study emphasizes the importance of a contingency approach to board research. Future works aimed at understanding what happens inside the boardroom should further investigate the impact of context and processes on board task performance (e.g. Ravasi and Zattoni, 2006).

\section{References}

Aguilera, R.V., and A. Cuervo-Cazurra (2004). 'Codes of good governance worldwide: what is the trigger?', Organization Studies, 25 (3): 417-446.

Amason, A.C. (1996). 'Distinguishing the effects of functional and dysfunctional conflict on strategic decisions making: Resolving a paradox for top management teams', Academy of Management Journal, 39 (1): 123-148.

Amason, A.C. and H.J. Sapienza (1997). 'The Effects of Top Management Team Size and Interaction Norms on Cognitive and Affective Conflict', Journal of Management, 23 (4): 495.

Andrews, K. (1980). 'Directors' responsibility for corporate strategy', Harvard Business Review, Nov.-Dec.: 174-184.

Bantel, K.A. and S.E. Jackson (1989). 'Top management innovations in banking: Does the composition of the top team make a difference?', Strategic Management Journal, 10: 107-124.

Baysinger B. and R.E. Hoskisson (1990). 'The Composition of Boards of Directors and Strategic Control: Effects on Corporate Strategy', Academy of Management Review, 15: $72-87$.

Baysinger B.D. and H.N. Butler (1985). 'Corporate Governance and the Board of Directors: Performance Effects of Changes in Board Composition', Journal of Law, Economics and Organization, 15: 72-87.

Berle A.A. and G.C. Means (1932). The Modern Corporation and Private Property. McMillan, New York.

Boyd, B. (1995). 'CEO duality and firm performance: A contingency model', Strategic Management Journal, 16 (4), 1995: 301-312.

Cadbury, A. (2002). Corporate governance and chairmanship. Oxford: Oxford University Press. 
Carpenter, M.A. and J.D. Westphal (2001). 'The Strategic Context of External Network Ties: Examining the Impact of Director Appointments on Board Involvement in Strategic Decision Making', Academy of Management Journal, 4 (4): 639-660.

Carter D.A., Simkins B.J., and W.G. Simpson (2003). 'Corporate Governance, Background diversity, and Firm Value', The Financial Review, 38, 33-53.

Daily C.M. and D.R. Dalton (1994). 'Bankruptcy and Corporate Governance: the impact of board composition and structure', Academy of management Journal, 37, 6, 1603-1617.

Daily, C.M., Dalton D.R., and A.A. Cannella (2003). 'Corporate Governance: Decades of Dialogue and Data', Academy of Management Review, 28 (3): 371-382.

Dalton D.R., Daily C.M., Ellstrand A.E. and J.L. Johnson (1998). 'Meta-Analytic Reviews of Board Composition, Leadership Structure, and Financial Performance', Strategic Management Journal, 19, 269-290.

Dalton D.R., Daily C.M., Johnson J.L. and A.E. Ellstrand (1999). 'Number of Directors and Financial Performance: A Meta-Analysis', Academy of Management Journal, 42, 674-686.

Davis J.H., Schoorman D.F., and L. Donaldson (1997). 'Toward a Stewardship Theory of Management', Academy of Management Review, 22, 20-47.

De Jong, H.W. (1997). 'The Governance Structure and Performance of Large European Corporations', Journal of Management and Governance, 1: 5-27.

Demb, A. and F.F. Neubauer (1992). The Corporate Board, New York: Oxford University Press.

Donaldson, L. and J.H. Davis (1991). 'Stewardship Theory or agency theory: CEO governance and shareholder returns', Australian Journal of Management, 16, 49-64.

Dutton J. and S. Jackson (1987). 'Categorizing strategic issues: links to organizational action', Academy of Management Review, 12, 76-90

Eisenhardt K.M. and Shoonhoven C.B. (1990). 'Organizational growth: Linking founding team, strategy, environment, and growth among U.S. semiconductor ventures, 1978 - 1988'. Administrative Science Quarterly, 35: 504-529.

Eisenhardt K.M., Kahwajy J.L. and L.J. Bourgeois III (1997). 'How management teams can have a good fight', Harvard Business Review, 75, 77-84

Eisenhardt, K.M. (1985). 'Control organizational and economic approaches', Management Science, 31 (2): 134-149. 
Erhardt N.L., Werbel J.D., and C.B. Shrader (2003). 'Board of Director Diversity and Firm Financial Performance', Corporate Governance: an International Review, Vol. 11, n. $2,102-111$.

Fama, E. and M.C. Jensen (1983). 'Separation of Ownership and Control', Journal of Law and Economics, 26, 301-325.

Fama, E.F. (1980). 'Agency Problems and the Theory of the Firm', Journal of Political Economy, 88, 288-307.

Finkelstein, S. and A.C. Mooney (2003). 'Not the Usual Suspects: How to Use the Board Process to Make Boards Better', Academy of Management Executive, 17(2): 101-113.

Forbes D.P. and F.J. Milliken (1999). 'Cognition and Corporate Governance: Understanding Boards of Directors as Strategic Decision-Making Groups', Academy of Management Review, 24, 489-505.

Fowler, F.J. (1993). Survey Research Methods, Newbury Park: Sage.

Garvin, D.A. and M.A. Roberto (2001). 'What you don't know about making decisions', Harvard Business Review, Sept.-Oct.

Groves R.M., Cialdini R.B. and M.P. Couper (1992). 'Understanding the decision to participate in a survey', Public Opinion Quarterly, 56, 475-495.

Hambrick D.C., Cho T.S. and M.J. Chen (1996). 'The Influence of Top Management Team Heterogeneity on Firms' Competitive Moves', Administrative Science Quarterly, 41 (4): 659-684.

Hermalin, B.E. and M.S. Weisbach (2003). 'Boards of directors as an endogenously determined institution: A survey of the economic literature', Economic Policy Review, April 9(1): 7-26.

Hillman A.J. and T. Dalziel (2003). 'Boards of Directors and Firm Performance: Integrating Agency and Resource Dependence Perspectives', The Academy of Management Review, 28, 383-396.

Hoffman L.R., Harburg E. and N.R.F. Maier (1962). 'Differences and disagreement as factors in creative group problem-solving', Journal of abnormal and social psychology, 64, 206-214.

Huse M. (2007). Boards, Governance and Value Creation. The Human Side of Corporate Governance. Cambridge University Press: Cambridge. 
Huse, M. (2005). 'Accountability and creating accountability: A framework for exploring behavioural perspectives of corporate governance', British Journal of Management, n. 16.

Huse, M., Minichilli, A. and Schøning, M. (2005). 'Corporate Boards as Assets for Operating in the New Europe: The Value of Process-Oriented Boardroom Dynamics', Organizational Dynamics, 34: 285-297

Jehn K. (1995). 'A Multimethod Examination of the Benefits and Detriments of Intragroup Conflicts', Administrative Science Quarterly, 40: 256-282.

Jensen M.C. and W.H. Meckling (1976). 'Theory of the Firm: Managerial Behaviour, Agency Costs and Ownership Structure', Journal of Financial Economics, 3, 305360.

Johnson J.L., Daily C.M. and A.E. Ellstrand (1996). 'Boards of Directors: A Review and Research Agenda', Journal of Management, 22, 409-438.

Judge W.Q. and C.P. Zeithaml (1992). 'Institutional and Strategic Choice Perspectives on Board Involvement in the Strategic Decision Process', The Academy of Management Journal, 35.

Kiel G.C. and G.J. Nicholson (2005). Evaluating Boards and Directors, Corporate Governance: an International Review, 13(5), 613-631.

Knight D., Pearce C.L., Smith K.G., Olian J.D., Sims H.P., Smith K.A., and P. Flood (1999). 'Top management team diversity, group process, and strategic consensus', Strategic Management Journal, 20, 5, 445-465

Kumar N., Stern L.W. and Anderson J.C. (1993). 'Conducting Interorganizational Research Using Key Informants', Academy of Management Journal, 36(6): 16331651.

Latane B., Williams K. and S. Harking (1979). 'Many hands make light the work: the causes and consequences of social loafing', Journal of Personality and Social Psychology, 37: 822-932.

Lau, D.C. and J.K. Murnighan (1988). 'Demographic Diversity and Faultlines: The Compositional Dynamics of Organizational Groups', Academy of Management Review, 23, 2, 325-340

Lorsch, J.W. and E. MacIver (1989). Pawns or Potentates. The Reality of America's Corporate Boards, Boston, HBS Press.

Mace, M. (1986). Directors: Myth and reality. Harvard Business School Press, Boston. 
Maier N.R.F. (1970). Problem solving and creativity. Brooks/Cole, Belmont, Calif.

McNulty T. and Pettigrew A. (1999). 'Strategists on the Board', Organization Studies, 20(1): 47-74.

Melis, A. (2000). 'Corporate Governance in Italy', Corporate Governance: An International Review, 8 (4): 347-355.

Miller C.C., Burke L.M. and W.H. Glick (1998). 'Cognitive diversity among upperechelon executives: implications for strategic decision processes', Strategic Management Journal, 19, 1, 39-58.

Milliken, F. and L. Martins (1996). 'Searching for common threads: understanding the multiple effects of diversity in organizational groups', Academy of Management Review, 21, 402-433.

Millstein I.M. and P.W. MacAvoy (1998). 'The Active Board of Directors and Performance of the Large Publicly Traded Corporation', Columbia Law Review, 98(5): 1283-1322.

Molteni, M. (1997). 'I sistemi di corporate governance nelle imprese italiane di medie e grandi dimensioni'. In: Molteni, M. (ed.), I sistemi di corporate governance nelle grandi imprese italiane, Milano, Egea.

Pearce J.A. and S.A. Zahra (1991). 'The Relative Power of CEOs and Boards of Directors: Associations with Corporate Performance', Strategic Management Journal, 2, 135-153.

Pelled L.H., Eisenhardt K.M. and K.R. Xin (1999). 'Exploring the Black Box: an Analysis of Work, Group Diversity, Conflict, and Performance', Administrative Science Quarterly, 44, 1-28.

Pettigrew A. and T. McNulty (1995). 'Power and Influence In and Around the Boardroom', Human Relations, 48(8): 845-873.

Pettigrew, A. (1992). 'On Studying Managerial Elites', Strategic Management Journal, $13,163-182$.

Pfeffer J. and G.R. Salancik (1978). The External Control of Organizations: A Resource Dependency Perspective, New York, Harper and Row.

Pfeffer, J. (1972). 'Size and Composition of Corporate Boards of Directors: The Organization and Its Environment', Administrative Science Quarterly, 17, 218-228. 
Pfeffer, J. (1983). 'Organizational Demography'. In L.L. Cummings and B.M. Staw (Eds.), Research in Organizational Behavior, vol. 5: 299-357. Greenwich: JAI Press.

Podsakoff, P.M., MacKenzie, S.B., Lee, J.Y. and N.P. Podsakoff (2003). 'Common method biases in behavioral research: A critical review of the literature and recommended remedies', Journal of Applied Psychology, 88: 879-903.

Priem R.L. and Price K.H. (1991). 'Process and Outcome Expectations for the Dialectical Inquiry, Devil's Advocacy, and Consensus Techniques of Strategic Decision Making', Group \& Organization Studies, 16(2): 205-225.

Pye, A. and A. Pettigrew (2005). 'Studying board context, process and dynamics: some challenges for the future', British Journal of Management, 16: 27-38.

Ravasi, D. and A. Zattoni (2006). 'Exploring the Political Side of Board Involvement in Strategy: A Study ofMixed-Ownership Institutions', Journal of Management Studies, 43(8), 1673-1703.

Roberts J., McNulty T. and P. Stiles (2005). 'Beyond agency conceptions of the work of the non-executive director: Creating accountability in the boardroom', British Journal of Management, 16: 5-26.

Robinson, G. and K. Dechant (1997). 'Building a business case for diversity', Academy of Management Executive, 11 (3): 21-31.

Ruigrok, W., Peck, S., Tacheva, S., Greve, P. and Y. Hu (2006). 'The Determinants and Effects of Board Nomination Committees', Journal of Management \& Governance, 10 (2): 119-148.

Schweiger D.M., Sandberg W.R., and J.W. Ragan (1986). 'Group approaches for improving strategic decision making: A comparative analysis of dialectical inquiry, devil's advocacy, and consensus', Academy of Management Journal, 29 (1): 51-72.

Shleifer A. and R.W. Vishny (1997). 'A Survey of Corporate Governance', The Journal of Finance, 52, 737-783.

Siegel, S. and N.J. Castellan (1988). Nonparametric Statistics for the Behavioral Sciences ( $2^{\text {nd }}$ ed.). McGraw-Hill, New York.

Simons T., Pelled H.L. and K.A. Smith (1999). 'Making use of difference: diversity, debate, and decision comprehensiveness in Top Management Teams', Academy of Management Journal, 42(6): 662-673.

Stiles, P. and B. Taylor (2001). Boards at work, Oxford University Press: Oxford. 
Strebel, P. (2004). 'The Case for Contingent Governance', Sloan Management Review, 45 (2), p.59-66.

Tourangeau, R., Rips, L.J. and K. Rasinski (2000). The psychology of survey response. Cambridge, Cambridge University Press.

Wanous J. and M. Youtz (1986). 'Solution diversity and the equality of group decisions', Academy of Management Journal, 29, 149-159.

Westphal, J. D. (1999). 'Collaboration in the boardroom: behavioural and performance consequences of CEO-Board social ties', Academy of Management Journal, 42, 1, 7-24.

Zahra S.A. and J.A. Pearce II (1989). 'Boards of Directors and Corporate Financial Performance: A Review and Integrative Model', Journal of Management, 15(2), 291-334.

Zahra, S.A. (1996). 'Governance, Ownership, and Corporate Entrepreneurship. The Moderating Impact of Industry Technological Opportunities', Academy of Management Journal, 39: 1713-1735.

Zahra, S.A., Neubaum, D.O. and M. Huse (2000). 'Entrepreneurship in Medium Size Companies: Exploring the Effects of Ownership and Governance Systems', Journal of Management, 26: 947-976.

Zattoni, A. (1999). 'The Structure of Corporate Groups: The Italian Case', Corporate Governance - An International Review, 7 (1): 38-48.

Zattoni, A. (2006). Assetti proprietari e corporate governance. Milano, Egea.

Zona F. and A. Zattoni (2007). 'Beyond the Black Box of Demography: Board Processes and Task Effectiveness Within Italian Firms', Corporate Governance: an International Review, 15(5): 852-864. 


\section{Tables and Figures}

Figure 1: The theoretical model

Board

characteristics
Board task -

performance

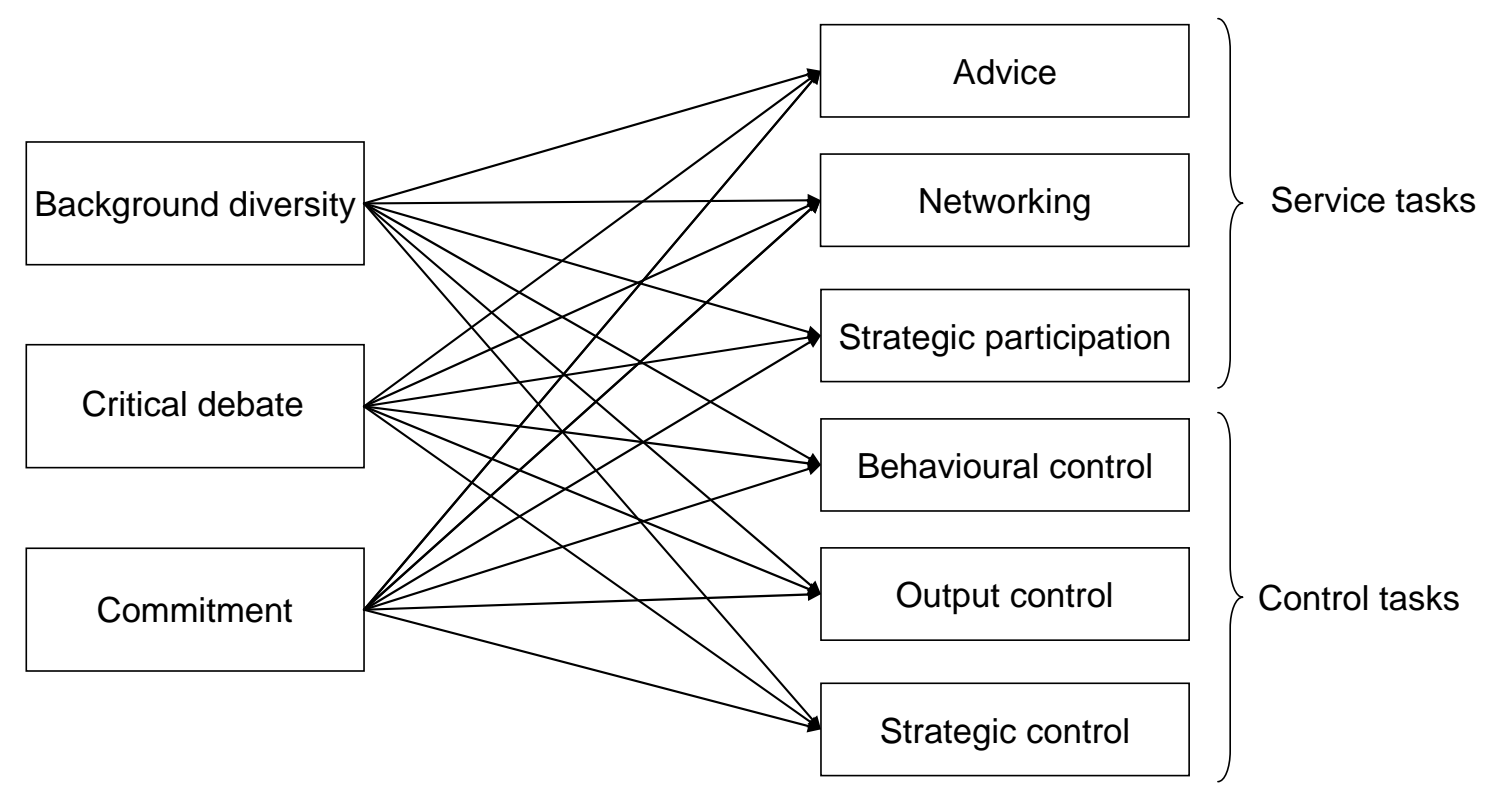


Table 1. Correlation analysis among the variables

\begin{tabular}{|c|c|c|c|c|c|c|c|c|c|c|c|c|c|c|c|c|c|c|}
\hline & Mean & $\begin{array}{l}\text { St.D } \\
\text { ev }\end{array}$ & Size & Regulat & Listing & Ceo dual & \# direct & Outsider & BM share & Diversity & Critical Deb. & Commit. & Advice & Network & Str.partic & Behav.cont & Output cont & Strat.contr \\
\hline Size & 5.55 & 1.59 & - & - & - & - & - & - & - & - & - & - & - & - & - & - & - & - \\
\hline Regulation & 3.01 & 1.57 & .09 & - & - & - & - & - & - & - & - & - & - & - & - & - & - & - \\
\hline Listing & .24 & .43 & .10 & .03 & - & - & - & - & - & - & - & - & - & - & - & - & - & - \\
\hline Ceo duality & .31 & .46 & -.07 & -.03 & .04 & - & - & - & - & - & - & - & - & - & - & - & - & - \\
\hline \# directors & 7.25 & 4.11 & $.13^{*}$ & .07 & $.30 * *$ & .04 & - & - & - & - & - & - & - & - & - & - & - & - \\
\hline Outsider ratio & .45 & .34 & .10 & .10 & $.34 * *$ & -.08 & $.46^{* *}$ & - & - & - & - & - & - & - & - & - & - & - \\
\hline BMsharehold. & .19 & .29 & $-.16^{* *}$ & -.08 & -.09 & -.07 & $-.18 * *$ & $-.12 *$ & - & - & - & - & - & - & - & - & - & - \\
\hline Bckg Diversity & 2.20 & 1.26 & $.16^{* *}$ & .05 & $.54 * *$ & -.05 & $.40 * *$ & $.48^{* *}$ & $-.14 *$ & - & - & - & - & - & - & - & - & - \\
\hline Critical debate & 2.06 & .88 & -.02 & .04 & -.05 & -.07 & -.07 & -.01 & .05 & -.03 & - & - & - & - & - & - & - & - \\
\hline Commitment & 3.57 & .64 & .07 & .11 & $.18^{* *}$ & -.05 & -.08 & -.02 & .08 & .04 & .00 & - & - & - & - & - & - & - \\
\hline Advice & 3.11 & .92 & -.03 & .10 & .09 & .00 & $-.17 * *$ & -.10 & .06 & -.09 & .10 & $.52 * *$ & - & - & - & - & - & - \\
\hline Network & 2.66 & 1.17 & -.05 & .11 & .17 & -.01 & .03 & .09 & $.16^{* *}$ & $.12^{*}$ & $.12 *$ & $.31 * *$ & $.37 *$ & - & - & - & - & - \\
\hline Strat. Particip. & 3.36 & 1.06 & -.09 & $.12 *$ & .06 & .01 & -.10 & $-.14 *$ & .05 & -.07 & .03 & $.54 * *$ & $.62 * *$ & $.36^{* *}$ & - & - & - & - \\
\hline Behav.control & 3.20 & .92 & .01 & $.14 *$ & $.18 * *$ & -.03 & .06 & -.03 & -.02 & -.04 & .05 & $.43 * *$ & $.60 * *$ & $.33 * *$ & $.52 * *$ & - & - & - \\
\hline Output control & 3.56 & .89 & .02 & $.15^{* *}$ & $.27 * *$ & .01 & .07 & -.01 & -.04 & .02 & -.02 & $.52 * *$ & $.63 * *$ & $.34 * *$ & $.66^{* *}$ & $.73 * *$ & - & - \\
\hline Strat.control & 3.79 & 2.56 & -.01 & .07 & .05 & .06 & -.01 & -.02 & -.04 & -.03 & -.01 & $.28^{* *}$ & $.34 * *$ & $.16^{* *}$ & $.31 * *$ & $.32 * *$ & $.33 * *$ & - \\
\hline
\end{tabular}

Pearson correlation coefficient, 1-tailed: $*<0.05 ; * *<0.01 \mathrm{~N}=301$ 
Table 2. Regression analyses

\begin{tabular}{|c|c|c|c|c|c|c|c|c|c|c|c|c|c|c|c|c|c|c|}
\hline & \multicolumn{3}{|c|}{ Advice } & \multicolumn{3}{|c|}{ Networking } & \multicolumn{3}{|c|}{ Strategic participation } & \multicolumn{3}{|c|}{ Behavioural control } & \multicolumn{3}{|c|}{ Output control } & \multicolumn{3}{|c|}{ Strategic control } \\
\hline & $I$ & II & III & $I$ & II & III & $I$ & II & III & $I$ & II & III & $I$ & II & III & $I$ & II & III \\
\hline Firm size & -.07 & -.04 & -.06 & -.09 & -.07 & -.09 & $-.17 *$ & $-.14 *$ & $-.17 * *$ & -.05 & -.05 & -.06 & -.04 & -.03 & -.05 & $\begin{array}{ll}-02 \\
\end{array}$ & -.01 & -.03 \\
\hline Regulation & $.15^{*}$ & $.17 * *$ & $.11^{*}$ & $.12 \dagger$ & $.13 *$ & .09 & $.17 * *$ & $.18^{* *}$ & $.12 *$ & $.16^{*}$ & $.16^{*}$ & $.12 *$ & $.15^{*}$ & $.16^{*}$ & $.11 *$ & .08 & .08 & .04 \\
\hline Listing & $.11 \dagger$ & $.19 * *$ & $.12 \dagger$ & $.17 * *$ & $.16^{*}$ & .10 & .08 & $.15^{*}$ & .05 & $.17 * *$ & $.18 * *$ & $.20 * *$ & $.28 * * *$ & $.31^{* * *}$ & $.27 * * *$ & .04 & .06 & .01 \\
\hline CEO duality & & -.01 & .04 & & -.00 & .02 & & -.02 & .02 & & -.06 & -.04 & & -.04 & -.01 & & .06 & .07 \\
\hline Outsider ratio & & -.04 & .00 & & .05 & .05 & & $-.14 *$ & $-.11 \dagger$ & & -.06 & .02 & & $-.13 \dagger$ & -.05 & & -.05 & -.03 \\
\hline BM sharehold. & & .09 & .05 & & $.20 * *$ & $.17 * *$ & & .08 & .03 & & .06 & .02 & & .05 & .01 & & -.03 & -.05 \\
\hline Critical debate & & & $.11 *$ & & & $.12 *$ & & & .05 & & & .06 & & & -.00 & & & .00 \\
\hline Backg diversity & & & $-.14 *$ & & & .01 & & & -.08 & & & $-.26 * * *$ & & & $-.20 * *$ & & & -.05 \\
\hline $\mathrm{Adj}^{2}$ & $.04 *$ & $.06 * *$ & $.31 * * *$ & $.04 * *$ & $.06 * *$ & $.14 * * *$ & $.04 * *$ & $.06 * *$ & $.38 * * *$ & $.04 * *$ & $.04 *$ & $.22 * * *$ & $.09 * * *$ & $.09^{* * *}$ & $.33 * * *$ & .00 & -.01 & $.05 * *$ \\
\hline F change & $3.1^{* *}$ & $3.3^{* *}$ & $30.4 * * *$ & $3.9^{* *}$ & $2.5^{*}$ & $8.9 * * *$ & $4.4 * *$ & $2.1 \dagger$ & $36.9 * * *$ & $4.7 * *$ & .62 & $19.4 * * *$ & $9.3 * * *$ & 1.1 & $28.8 * * *$ & .64 & .41 & $6.7 * * *$ \\
\hline
\end{tabular}

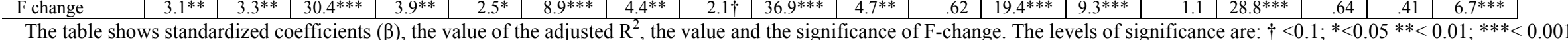

The table shows standardized coeflicients $(\beta)$, the value of the ac
Number of cases:

- Advice, network, strategic

- Behavioural control: 24

- Strategic control: 249 
Table 3. Significant predictors on different board tasks

\begin{tabular}{|c|c|c|}
\hline & Service tasks & Control tasks \\
\hline Internal focus & $\begin{array}{l}\text { Advice } \\
\text { - Regulation }(+) \\
\text { - } \text { Listing }(+) \\
\text { - } \text { Critical debate }(+) \\
\text { - } \text { Background diversity }(-) \\
\text { - } \text { Commitment }(+)\end{array}$ & $\begin{array}{l}\text { Behavioural control } \\
\text { - Regulation }(+) \\
\text { - } \text { Listing }(+) \\
\text { - } \text { Board size }(+) \\
\text { - } \text { Background diversity (-) } \\
\text { - } \text { Commitment }(+)\end{array}$ \\
\hline External focus & $\begin{array}{l}\text { Networking } \\
\text { - Board shareholding }(+) \\
\text { - Critical debate }(+) \\
\text { - Commitment }(+)\end{array}$ & $\begin{array}{l}\text { Output control } \\
\text { - Regulation }(+) \\
\text { - Listing }(+) \\
\text { - } \text { Board size }(+) \\
\text { - } \text { Diversity }(-) \\
\text { - } \text { Commitment (+) }\end{array}$ \\
\hline Strategic focus & $\begin{array}{l}\text { Strategic participation } \\
\text { - Firm size }(-) \\
\text { - Regulation }(+) \\
\text { - Outsider ratio }(-) \\
\text { - } \text { Commitment }(+)\end{array}$ & $\begin{array}{l}\text { Strategic control } \\
\text { - Commitment }(+)\end{array}$ \\
\hline
\end{tabular}


Appendix. Variables and measures

\section{Dependent variables (Control Tasks)}

\section{Behavioural control}

- The board is actively involved in monitoring that all the internal behaviours are adequately controlled

- The board is actively involved in defining behavioural guidelines for divisional and functional managers

- The board is actively involved in supervising the CEO

Output control

- The board controls that the activities are well organized

- The board develops plan and budgets

- The board keeps informed on the financial position of the company

Strategic control

- The board actively monitors and evaluates strategic decisions

\section{Dependent variables (Service Tasks)}

Advice

- The board contributes on management issues

- The board contributes on financial issues

- The board contributes on technical issues

- The board contributes on market issues

- The board contributes on legal issues and taxation

Networking

- The board provides linkages to important external stakeholders (banks, financial institutions, customers, public authorities...)

- The board provides the firm with external legitimacy and reputation

Strategic participation

- The board is actively involved in promoting strategic initiatives

- The board is actively involved in long-term strategic decision-making

- The board is actively involved in implementing long term strategic decision-making

\section{Independent variables}

Commitment

- Directors examine information before meetings

- Directors actively collect further information to those supplied by managers

- Directors devote all the time needed to accomplish with their tasks

- Directors are available to fulfil board activities

- Directors effectively use their knowledge

- Directors makes useful questions to proposals advanced by managers

- Directors raise critical points during meetings

Critical debate

- There are conflict and disagreements on the decisions to be taken during meetings

- There are conflict and disagreements on the firm's legitimate stakeholders

- There are conflict and disagreements on the general purpose of the firm

- There are conflict and disagreements on the board working styles

- There are conflict and disagreements on the decision process

- There are conflict and disagreements among directors 